EXTENDED REPORT

\title{
Prognostic laboratory markers of joint damage in rheumatoid arthritis
}

\author{
E Lindqvist, K Eberhardt, K Bendtzen, D Heinegård, T Saxne
}

Ann Rheum Dis 2005;64:196-201. doi: 10.1136/ard.2003.019992

See end of article for authors' affiliations ....................

Correspondence to: Dr Elisabet Lindquist, Department of Rheumatology, Lund University Hospital, S-221 85 Lund, Sweden; elisabet. lindqvist@reum.lu.se

Accepted 6 July 2004 Published Online First 30 September 2004

\begin{abstract}
Objective: To investigate whether determination of a set of laboratory markers at baseline provides prognostic information on joint damage in hands and feet in rheumatoid arthritis.

Methods: 183 patients with early rheumatoid arthritis included in a prospective study were examined. Radiographic changes in hands and feet at 5 and 10 years after inclusion were evaluated (Larsen). The markers analysed were: erythrocyte sedimentation rate (ESR); HLA-DRB alleles typed by restriction fragment length polymorphism; and C reactive protein, cartilage oligomeric matrix protein (COMP), rheumatoid factor (RF) (lgG, $\lg A$, and $\lg M$ subtypes), antibodies against cyclic citrullinated peptide (antiCCP), and antibodies against interleukin $1 \alpha$ (anti-IL $1 \alpha$ ), analysed by immunoassays. Multiple linear regression with backward elimination was used to determine the prognostic value of the variables.

Results: 117/176 patients were positive for IgG RF, 138/176 for lgA RF, 139/176 for lgM RF, 140/176 for anti-CCP, and $40 / 182$ for anti-IL $1 \alpha$. After five years, ESR, the presence of IgA RF, serum COMP, and the presence of anti-CCP were significantly associated with more severe joint damage, and the presence of anti-IL $1 \alpha$ with less severe joint damage. Baseline $C$ reactive protein and anti-CCP predicted radiographic outcome after 10 years. A stronger prediction was obtained by combining the prognostic factors.

Conclusions: Early determination of anti-CCP, IgA RF, anti-IL-1 $\alpha, E S R, C$ reactive protein, and COMP predicted the development of joint damage in hands and feet in this cohort. A combination of these measures reflecting different aspects of the disease process should be useful for evaluating prognosis in individual patients with early rheumatoid arthritis.
\end{abstract}

$\mathrm{R}$ heumatoid arthritis follows a variable course and the lack of reliable prognostic factors that are useful at disease onset is well recognised by practising rheumatologists. Outcome in this disease is complex and relates to several entities such as disease activity, functional status, joint damage, and patients' perception of general health. Synovitis may explain most of the early symptoms and is also considered to contribute to the development of joint damage and disability. The correlation between inflammation and joint damage has been studied extensively, especially the relevance of inflammatory variables such as $\mathrm{C}$ reactive protein and erythrocyte sedimentation rate (ESR). ${ }^{1-4}$ Although there is a link between inflammation and the development of joint damage it is well established that damage may progress in spite of decreased inflammatory activity, and erosions may develop in patients who have few clinical signs of inflammation. Thus it has been suggested that pathological processes other than inflammation are involved in the destructive process. ${ }^{5-7}$

In this study we focused on the destructive process and used joint damage in the hands and feet, evaluated on radiographs, as the outcome variable. We selected several laboratory variables with suggested prognostic potential and tested their value in a well defined cohort of patients with early rheumatoid arthritis. ${ }^{8}$ The variables were ESR and $\mathrm{C}$ reactive protein, reflecting inflammation; cartilage oligomeric matrix protein (COMP), a marker of cartilage turnover with putative roles in disease chronicity'; and a set of autoantibodies: rheumatoid factor (RF) of IgG, IgA, and IgM type, anti-cyclic citrullinated peptide antibodies (anti-CCP), interleukin $1 \alpha$ antibodies (anti-ILl $\alpha$ ), and shared epitope.

Molecular markers from joint tissue matrix could be used to reflect the destructive process in rheumatoid arthritis. ${ }^{10}$ Increased serum levels of COMP have been found to correlate with large joint destruction in patients with this disease. ${ }^{11}$ It has also been shown that COMP is a measure of tissue processes that are distinct from the reactions in inflammation. ${ }^{12-14}$

$\mathrm{RF}$ and the more recently described anti-CCP, ${ }^{15-17}$ which is reported to be more specific for rheumatoid arthritis than RF, have both been shown to be associated with more severe joint damage. ${ }^{18-26}$ The different subtypes of RF have also been examined in relation to joint damage, and some studies have found IgA RF to be more related to damage, ${ }^{27-29}$ but the findings are conflicting. ${ }^{30} 31$

ILl $\alpha$ is an important proinflammatory cytokine in rheumatoid arthritis, and naturally occurring anti-ILl $\alpha$ antibodies were first reported in $1989 .{ }^{32}$ These antibodies bind with high affinity to ILl $\alpha$, thereby preventing binding of ILl $\alpha$ to its receptors and thus neutralising the biological activity of the cytokine. ${ }^{32}{ }^{33}$ It has been shown that patients with arthritis who carry the anti-ILl $\alpha$ develop less destructive disease. ${ }^{34-37}$ The reported frequency of anti-ILl $\alpha$ in the population varies from $10 \%$ to $60 \%$, depending on age, sex, and assay sensitivity. ${ }^{38}$

Genetic predictors for rheumatoid arthritis, mainly the HLA-DRBI alleles, have been investigated but the results are inconsistent in relation to prognosis for joint damage, disability, and disease persistence. ${ }^{24}{ }^{39-41}$

In this report, we sought to determine whether a combination of ESR, $C$ reactive protein, COMP, shared epitope, RF (IgG, IgA, and IgM types), anti-CCP, and antiILl $\alpha$ provides prognostic information on the development of joint damage in the hands and feet after five and 10 years in a prospective study of early rheumatoid arthritis.

Abbreviations: anti-CCP, antibodies against cyclic citrullinated peptide; COMP, cartilage oligomeric matrix protein; DMARD, disease modifying antirheumatic drug; IL $1 \alpha$, interleukin $1 \alpha$; RF, rheumatoid factor 
Table 1 Baseline characteristics of the 183 patients with early rheumatoid arthritis

\begin{tabular}{ll}
\hline Age at onset (years) & $51(12.4)$ \\
Female/male (n) & $116 / 66$ \\
Presence of "shared epitope" (\%) & 85 \\
C reactive protein (mg/l) & $27(33)$ \\
ESR (mm/h) & $36(28)$ \\
COMP (U/I) & $11.9(3.7)$ \\
Larsen at baseline (U) & $8(9)$ \\
IgG RF positivity (\%) & 67 \\
IgA RF positivity (\%) & 78 \\
IgM RF positivity (\%) & 79 \\
Anti-CCP positivity (\%) & 80 \\
Anti-ILl $\alpha$ positivity (\%) & 22 \\
\hline
\end{tabular}

Continuous variables are expressed as means (SD).

Anti-CCP, antibodies against cyclic citrullinated peptide; anti-ILI $\alpha$, antibodies against interleukin $1 \alpha$; COMP, cartilage oligomeric matrix protein; ESR, erythrocyte sedimentation rate; Larsen, Larsen radiographic score $^{44} ; \mathrm{RF}$, rheumatoid factor; U, units.

\section{METHODS}

All new patients with definite rheumatoid arthritis according to the 1958 American Rheumatism Association (ARA) criteria were included in a prospective study from 1985 to 1989 at the department of rheumatology at Lund University Hospital in southern Sweden. All consecutive patients aged 18 years or older with duration of symptoms for less than two years were included. Most patients were referred from primary health care units as a result of a special campaign to recruit cases of recent onset. The study comprises 183 patients ( 116 women and $67 \mathrm{men}$ ). Their mean (SD) age was 51.2 (12.4) years and the mean duration of symptoms at inclusion in the study was 11.1 (6.1) months. All patients, irrespective of disease activity, were included and followed prospectively at least annually at a team care unit. Patients with active disease were offered treatment with disease modifying antirheumatic drugs (DMARDs) throughout the study according to general clinical practice, which changed during the study period. Early in the study D-penicillamine and antimalarial agents were the most commonly used DMARDs, while at the 10 year follow up $23 \%$ of the patients were being treated with methotrexate, which was then the most commonly used drug. During the first five years, 13 patients were treated with methotrexate, while from year 5 to 10,46 patients were treated with methotrexate. The whole cohort has been followed for at least 10 years, and the clinical outcome is presented extensively elsewhere. ${ }^{42}$

\section{Radiographic evaluation}

In the present study radiographic findings in hands and feet at years 5 and 10 were used as outcome variables. Radiographic outcome over the first 10 years and the scoring methodology were described in detail previously. ${ }^{43}$ In brief, radiographs of hands and feet (standard film in posteroanterior projection) were obtained annually from inclusion to year 5 and at year 10. Joint damage caused by rheumatoid arthritis was evaluated according to Larsen et al. ${ }^{44}$ Thirty two joints in the hands and feet were assessed. Each joint was compared with a standard reference film and changes were graded from $0-5$, where a score of $\geqslant 2$ represents erosive disease. A joint damage score was calculated by adding all scores, the wrist multiplied by 5 , resulting in a range of 0 to $200 .^{43}$ The scoring was made by one of two assessors; years 0 5 were scored in chronological order and the 10 year evaluations were scored separately. Scoring reliability (interand intraobserver, chronological order versus separately) was evaluated using the intraclass correlation coefficient and varied from 0.92 to $0.99 .^{43}$

\section{Biochemical analyses}

Blood samples were collected from all patients at inclusion in the study. ESR was determined according to Westergren and $C$ reactive protein by an electroimmunoassay. ${ }^{45}$ HLA-DRB alleles were typed by restriction fragment length polymorphism analysis with sequence specific primers, as previously described. ${ }^{39}$ EDTA treated plasma and sera were frozen in aliquots and stored at $-80^{\circ} \mathrm{C}$. Serum COMP was measured with a commercial sandwich enzyme linked immunosorbent assay (ELISA) using two monoclonal antibodies directed against separate antigenic determinants on the human COMP molecule (AnaMar Medical, Lund, Sweden). The detection limit was $<0.1 \mathrm{U} / \mathrm{l}$ and the intra- and interassay coefficient of variation was $<5 \%$. RF (IgG, IgA, and $\operatorname{Ig} M$ subtypes) was analysed by ELISA using commercial kits (Inova Diagnostics, San Diego, California, USA) according to the manufacturer's instructions. Rabbit IgG was used on the solid phase. The limit for a positive result was set to $>6$ IU. Anti-CCP was analysed by ELISA using a commercial kit (Inova Diagnostics) in which a synthetic cyclic citrullinated peptide is used as antigen. The lowest value for a positive outcome was set to $\geqslant 20 \mathrm{U}$. Anti-ILl $\alpha$ were analysed by radioimmunoassay as described previously. ${ }^{37}$ The limit for positive results for anti-ILl $\alpha$ was defined as a binding of $>10 \%$.

The study was approved by the ethics committee of Lund University.

\section{Statistical analysis}

Comparisons between groups were analysed by the MannWhitney U test, Wilcoxon's test, or the $\chi^{2}$ test as appropriate. Pearson correlation coefficients expressed the relations between the assessed variables. Multiple linear regression with backward elimination was carried out to decide the degree of explanation of the different variables to the Larsen score at years 5 and 10. The following independent variables were entered as continuous variables: ESR, C reactive protein, COMP, and age at inclusion. Sex, RF (IgG, IgA, and IgM subtypes), anti-CCP, anti-ILl $\alpha$, and presence of shared epitope were entered as dichotomised independent variables. The variance inflation factor (VIF) was used to check for colinearity between the independent variables. All tests were two tailed and the limit value for significance and elimination in the regression analysis was set at $\mathrm{p}<0.05$.

\section{RESULTS}

The baseline characteristics of the patients are given in table 1. After 10 years 168 patients were still being followed and 157 underwent the radiographic evaluation. Of the 24 patients missing the 10 year radiographic evaluation, 15 had died, five had moved from the area, three were excluded because of old age or other diseases, and one refused to undergo the examination. The median (interquartile range) Larsen score at year 5 was 42 (17 to 60), with a range from 0 to 152 , and at year 10 it was 54 (28 to 80$)$, with a range from 0 to 162 .

At inclusion, 117 of 176 patients $(66 \%)$ were positive for IgG RF, 138 of 176 (78\%) for IgA RF, 139 of 176 (79\%) for IgM RF, 140 of $176(80 \%)$ for anti-CCP, and 40 of $182(22 \%)$ for anti-ILl $\alpha$. The concordance between the various types of RF and anti-CCP antibodies was high. Over half the patients (101 of $176(57 \%)$ ) had all three types of RF and anti-CCP. In all, 170 of the patients were genotyped and of these 145 $(85 \%)$ carried the shared epitope. Fifty four $(32 \%)$ carried the epitope on both alleles.

\section{Correlations}

Table 2 shows the correlation coefficients for the variables assessed. ESR and C reactive protein were strongly 


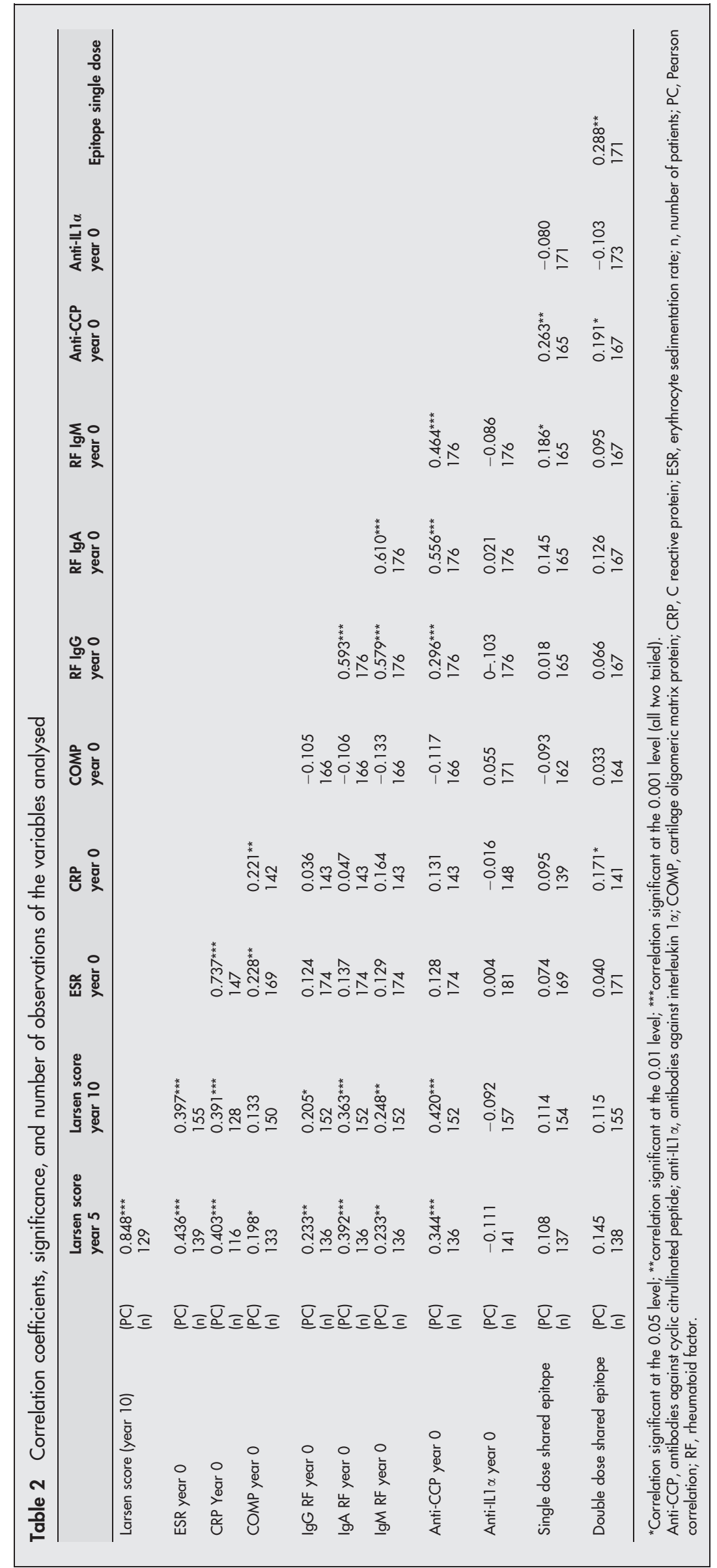


Table 3 Final step in multilinear regression analysis with backward elimination

\begin{tabular}{|c|c|c|c|c|c|c|}
\hline & \multicolumn{2}{|c|}{$\begin{array}{l}\text { Unstandardised } \\
\text { coefficients }\end{array}$} & \multirow[b]{2}{*}{ p Value } & \multicolumn{2}{|l|}{$95 \% \mathrm{Cl}$ for B } & \multirow{2}{*}{$\begin{array}{l}\text { Colinearity statistic } \\
\text { (VIF) }\end{array}$} \\
\hline & B & SE & & Lower bound & Upper bound & \\
\hline \multicolumn{7}{|l|}{ (Constant) } \\
\hline ESR & 0.333 & 0.077 & 0.000 & 0.180 & 0.487 & \\
\hline COMP & 1.637 & 0.662 & 0.015 & 0.323 & 2.950 & 1.086 \\
\hline $\lg A$ RF & 19.132 & 6.803 & 0.006 & 5.638 & 32.627 & 1.558 \\
\hline Anti-CCP & 14.465 & 6.313 & 0.024 & 1.942 & 26.988 & 1.551 \\
\hline Anti-ILl $\alpha$ & -13.341 & 4.977 & 0.009 & -23.215 & -3.467 & 1.023 \\
\hline
\end{tabular}

correlated. The various subtypes of RF showed relatively strong correlation. Anti-CCP had the highest correlation with IgA RF and in descending order with IgM and IgG RF. ESR, $C$ reactive protein, and IgA RF were correlated significantly but rather weakly with the Larsen score, while COMP showed only a weak correlation with ESR, C reactive protein, and Larsen score at year 5 .

\section{Regression analyses}

ESR, COMP, IgA RF, anti-CCP, and anti-IL- $1 \alpha$ were found to explain $44 \%$ of the variance in Larsen score at year 5 . The last step of the regression analysis is given in table 3. Increased ESR and COMP levels and the presence of IgA RF and antiCCP antibodies were significantly associated with more severe joint damage; the presence of anti-ILl $\alpha$ was associated with less severe joint damage. Presence of shared epitope, age at inclusion in the study, and sex did not influence the results after either five or 10 years. The variance inflation factor (VIF) being close to 1 shows that the measurements represent different entities, except for IgA RF and anti-CCP, where a VIF of 1.6 indicates a certain degree of multicolinearity.

Thirty two per cent of the variance in Larsen score year 10 could be explained by $\mathrm{C}$ reactive protein and anti-CCP. AntiILl $\alpha$, IgA RF, and COMP were not significantly associated with Larsen scores at year 10 ( $\mathrm{p}$ values $0.06,0.11$, and 0.14 , respectively). The last step of the regression analyses is given in table 4.

To be able to use these findings to predict the development of joint damage in individual patients, an interpretation of the results from the analysis with the Larsen score for year 5 as the dependent variable is given in table $5 \mathrm{~A}$ and for year 10 in table 5B. Importantly, if more than one risk factor was present in the same patient, the effect was additive.

Owing to missing data in one or more variables, only 107 of 177 patients at year 5 and 119 of 168 at year 10 could be included in the regression analyses. At year 5, patients not included in the analyses had higher $C$ reactive protein values $(\mathrm{p}<0.05)$ and tended to be IgA RF positive less often $(p=0.09)$. At year 10, patients not included in the analyses were older $(p<0.01)$ and more often men $(p<0.05)$. An increased mortality among older men contributed to this. ${ }^{46}$ No other significant differences between assessed variables were found at any time point.

\section{DISCUSSION}

In this study we have shown that laboratory variables explained about half the variance in the Larsen score after five years. Serum COMP, anti-CCP, and anti-ILl $\alpha$ added some prognostic information to ESR and IgA RF, which were the strongest predictors of joint damage in the hands and feet after five years. After 10 years, anti-CCP was the only significant predictor, together with $\mathrm{C}$ reactive protein. We found that inflammatory variables were related to joint destruction, in agreement with many earlier reports. ${ }^{343}$ The various RF subtypes were intercorrelated. However, as in many previous studies, IgA RF turned out to have the best prognostic power after five years. The lack of significant association for IgA RF at year 10 could be caused by the existing colinearity between anti-CCP and IgA RF. We have earlier reported that IgG RF showed the strongest relation to joint damage after two years of follow up in this cohort. ${ }^{47}$ The discrepant findings might be explained by the shorter follow up period, different assessment methods, and fewer patients.

Furthermore, the presence of anti-CCP predicted a more destructive form of rheumatoid arthritis after both five and 10 years. The 5 year findings are in concordance with other studies. ${ }^{19-21}$ The current study extends these results by showing that this also holds true in a longer perspective. Anti-CCP appears early in the disease course and has a high specificity for rheumatoid arthritis. ${ }^{48}$ Anti-CCP might therefore be a valuable additional predictive tool in the management of this disease. The strong concordance between RFs and anti-CCP means that very few patients lacking RF will be positive for anti-CCP. This limits the clinical value of using both antibodies.

We also found that COMP, a marker reflecting another aspect of the disease process, had additive predictive value.

Table 4 Last step in multilinear regression analysis with backward elimination

\begin{tabular}{|c|c|c|c|c|c|c|}
\hline & \multicolumn{2}{|c|}{$\begin{array}{l}\text { Unstandardised } \\
\text { coefficients }\end{array}$} & \multirow[b]{2}{*}{$p$ Value } & \multicolumn{2}{|l|}{$95 \% \mathrm{Cl}$ for B } & \multirow{2}{*}{$\begin{array}{l}\text { Colinearity statistic } \\
\text { (VIF) }\end{array}$} \\
\hline & B & SE & & Lower bound & Upper bound & \\
\hline \multicolumn{7}{|l|}{ (Constant) } \\
\hline CRP year 0 & 0.4175 & 0.097 & 0.000 & 0.233 & 0.617 & 1.042 \\
\hline Anti-CCP & 36.609 & 7.201 & 0.000 & 22.346 & 50.872 & 1.042 \\
\hline
\end{tabular}

Larsen score year 10 is the dependent variable and the laboratory analyses are used as independent variables. Anti-CCP, antibodies against cyclic citrullinated peptide; $\mathrm{Cl}$, confidence interval; $\mathrm{CRP}, \mathrm{C}$ reactive protein; $\mathrm{SE}$, standard error; VIF, variance inflation factor. 
Table 5 Interpretation of the results from regression analysis useful for the prediction of joint damage in individual patients

\begin{tabular}{|c|c|}
\hline $\begin{array}{l}\text { Variable assessed } \\
\text { at baseline }\end{array}$ & Interpretation \\
\hline \multicolumn{2}{|c|}{ (A) Larsen score year 5 as dependent variable } \\
\hline ESR & An increase of $1 \mathrm{~mm} / \mathrm{h}$ in ESR corresponded to an average increase in Larsen score of 0.3 \\
\hline $\lg A$ RF & With positive IgA RF the Larsen score was on average 19.1 units higher \\
\hline Anti-ILl $\alpha$ & With positive anti-IL1 $\alpha$ the Larsen score was on average 13.3 units lower \\
\hline COMP & An increase of 1 unit corresponded to an average increase in Larsen score of 1.6 \\
\hline Anti-CCP & With positive anti-CCP the Larsen score was on average 14.4 units higher \\
\hline \multicolumn{2}{|c|}{ (B) Larsen score year 10 as dependent variable } \\
\hline CRP & An increase of $1 \mathrm{mg} / \mathrm{l}$ corresponded to an average increase in Larsen score of 0.42 \\
\hline Anti-CCP & With positive anti-CCP the Larsen score was on average 37 units higher \\
\hline
\end{tabular}

COMP shows very weak associations with both inflammatory indices and autoantibodies. This protein was originally isolated and characterised as a cartilage matrix component but has subsequently also been found in other tissues-for example, synovium, tendon, and meniscus (for references, see Larsson et $\left.a l^{14}\right)$. However, numerous studies in human and experimental arthritis clearly indicate that changes in serum levels of COMP are related to processes in cartilage. ${ }^{101214}$ Thus serum COMP is a potential marker of changes in cartilage turnover, and increased serum levels may occur early in the course of rheumatoid arthritis as a sign of cartilage involvement. The present study lends further support to this hypothesis by showing that the serum concentration of COMP at inclusion was predictive of future small joint damage. The original COMP assay and the one used in the present study measure both intact and fragmented COMP, which limits the possibility of discriminating between matrix synthesis and degradation. ${ }^{9}$ Refinement of the technology enabling specific measurement of select fragments will most probably increase the prognostic value of COMP. The observations regarding COMP in this study are at variance with findings in a previous study of ours, where COMP was not found to be predictive of small joint damage in a subset of patients from the early rheumatoid arthritis cohort. ${ }^{49}$ A possible explanation for this discrepancy is that a different COMP assay with a polyclonal antibody was used. ${ }^{9}$

The naturally occurring anti-ILl $\alpha$ antibodies were found to predict less severe radiographic outcome in this cohort. This finding is in agreement with some previous studies, ${ }^{34-37}$ but it may be apparent only with prolonged disease, because a two year follow up in an early rheumatoid cohort failed to show this relation..$^{50}$ This latter study did not correct for the presence of RF and anti-CCP, which may have contributed to the discrepant results.

The presence of shared epitope in single or double dose did not provide any predictive information on the development of joint damage in this study. We have earlier found that the presence of shared epitope was not related to functional outcome. ${ }^{42}$ These findings are in agreement with several other reports indicating that genetic screening should not be done routinely in early arthritis clinics. ${ }^{40}$

The variance of radiographic damage that could be explained in our multivariate models was $44 \%$ after five years and $32 \%$ after 10 years by baseline laboratory assessments. Even if the degree of explanation is fairly moderate our findings can be used as guidance when trying to predict the risk of joint damage in individual patients, as shown in table 5. So far no other better predictors have been recognised. The prognostic value of our laboratory assessments was somewhat less apparent for the 10 year outcome.
One explanation for this might be that about $75 \%$ of the joint damage had already occurred after five years. ${ }^{43}$ Furthermore, the therapeutic strategy used in this cohort changed over time. During the first five years only $7 \%$ of the patients $(n=13)$ were treated with methotrexate, compared with $27 \%$ $(\mathrm{n}=46)$ during the following five years. Although this figure is low compared with the current strategy, it could still influence the results, as methotrexate has been shown to modify progression of joint damage. ${ }^{51}$ Modification of the disease course by effective treatment strategies will increasingly hamper the evaluation of new potential prognostic markers in the future. ${ }^{52}$ Thus our cohort of conservatively treated patients (in comparison with current standards) will be valuable for such studies.

\section{Conclusions}

In this prospective early rheumatoid arthritis cohort, ESR/ $\mathrm{C}$ reactive protein, COMP, and the presence of IgA RF, antiCCP, and anti-ILl $\alpha$ antibodies assessed at presentation provided prognostic information on future joint destruction. The laboratory measures used were selected to reflect different aspects of the disease process. The combination of markers was found to yield additive prognostic information.

\section{ACKNOWLEDGEMENTS}

Grants were obtained from the Swedish Medical Research Council, the Österlund and Kock Foundations, the King Gustaf V 80-year Fund, the medical faculty of Lund University, the Danish Rheumatism Foundation, and the Swedish Rheumatism Foundation.

\section{Authors' affiliations}

E Lindqvist, K Eberhardt, T Saxne, Department of Rheumatology, Lund University Hospital, Lund, Sweden

K Bendtzen, Institute for Inflammation Research, Rigshospitalet National University Hospital, Copenhagen, Denmark

D Heinegård, Department of Cell and Molecular Biology, Section for Connective Tissue Biology, Lund University

\section{REFERENCES}

1 van Leeuwen MA, van Rijswijk MH, Sluiter WJ, van Riel PL, Kuper IH, van de Putte LB, et al. Individual relationship between progression of radiological damage and the acute phase response in early rheumatoid arthritis. Towards development of a decision support system. J Rheumatol 1997:24:20-7.

2 Matsuda Y, Yamanaka H, Higami K, Kashiwazaki S. Time lag between active joint inflammation and radiological progression in patients with early rheumatoid arthritis. J Rheumatol 1998;25:427-32.

3 Graudal N, Tarp U, Jurik AG, Galloe AM, Garred P, Milman N, et al. Inflammatory patterns in rheumatoid arthritis estimated by the number of swollen and tender joints, the erythrocyte sedimentation rate, and hemoglobin: longterm course and association to radiographic progression. J Rheumatol 2000;27:47-57.

4 Plant MJ, Williams AL, O'Sullivan MM, Lewis PA, Coles EC, Jessop JD. Relationship between time-integrated $\mathrm{C}$-reactive protein levels and radiologic 
progression in patients with rheumatoid arthritis. Arthritis Rheum 2000;43: 1473-7.

5 Mulherin D, Fitzgerald O, Bresnihan B. Clinical improvement and radiological deterioration in rheumatoid arthritis: evidence that the pathogenesis of synovial inflammation and articular erosion may differ. Br J Rheumatol 1996;35:1263-8.

6 Kirwan JR. The relationship between synovitis and erosions in rheumatoid arthritis. Br J Rheumatol 1997;36:225-8.

7 van den Berg WB. Uncoupling of inflammatory and destructive mechanisms in arthritis. Semin Arthritis Rheum 2001;30(5 suppl 2):7-16.

8 Eberhardt KB, Rydgren LC, Pettersson H, Wollheim FA. Early rheumatoid arthritis - onset, course, and outcome over 2 years. Rheumatol Int 1990; 10:135-42.

9 Saxne T, Heinegard D. Cartilage oligomeric matrix protein: a novel marker of cartilage turnover detectable in synovial fluid and blood. BrJ Rheumatol 1992;31:583-91.

10 Saxne T, Mansson B. Molecular markers for assessment of cartilage damage in rheumatoid arthritis. In: Firestein G, Panayi GS, Wollheim FA, eds. Rheumatoid arthritis: new frontiers in pathogenesis and treatment. Oxford: Oxford University Press, 2000:291-304.

11 Mansson B, Carey D, Alini M, lonescu M, Rosenberg LC, Poole AR, et al. Cartilage and bone metabolism in rheumatoid arthritis. Differences between rapid and slow progression of disease identified by serum markers of cartilage metabolism. J Clin Invest 1995;95:1071-7.

12 Joosten LA, Helsen MM, Saxne T, van De Loo FA, Heinegard D, van den Berg WB. IL-1 alpha beta blockade prevents cartilage and bone destruction in murine type II collagen-induced arthritis, whereas TNF-alpha blockade only ameliorates joint inflammation. J Immunol 1999; 163:5049-55.

13 Roux-Lombard P, Eberhardt K, Saxne T, Dayer JM, Wollheim FA. Cytokines, metalloproteinases, their inhibitors and cartilage oligomeric matrix protein: relationship to radiological progression and inflammation in early rheumatoid arthritis. A prospective 5-year study. Rheumatology (Oxford) 2001;40:544-51.

14 Larsson E, Erlandsson HH, Lorentzen JC, Larsson A, Mansson B, Klareskog L, et al. Serum concentrations of cartilage oligomeric matrix protein, fibrinogen and hyaluronan distinguish inflammation and cartilage destruction in experimental arthritis in rats. Rheumatology (Oxford) 2002;41:996-1000.

15 Young BJ, Mallya RK, Leslie RD, Clark CJ, Hamblin TJ. Anti-keratin antibodies in rheumatoid arthritis. BMJ, 1979;ii, 97-9.

16 Schellekens GA, de Jong BA, van den Hoogen $F H$, van de Putte $L B$, van Venrooii WJ. Citrulline is an essential constituent of antigenic determinants recognized by rheumatoid arthritis-specific autoantibodies. J Clin Invest 1998;101:273-81.

17 van Venrooij WJ, Pruijn GJ. Citrullination: a small change for a protein with great consequences for rheumatoid arthritis. Arthritis Res 2000;2:249-51.

18 Visser H, le Cessie S, Vos K, Breedveld FC, Hazes JM. How to diagnose rheumatoid arthritis early: a prediction model for persistent (erosive) arthritis. Arthritis Rheum 2002;46:357-65.

19 Kroot EJ, de Jong BA, van Leeuwen MA, Swinkels $H$, van den Hoogen FH, van't Hof $M$, et al. The prognostic value of anti-cyclic citrullinated peptide antibody in patients with recent-onset rheumatoid arthritis. Arthritis Rheum 2000;43:1831-5.

20 Meyer O, Labarre C, Dougados M, Goupille P, Cantagrel A, Dubois A, et al. Anticitrullinated protein/peptide antibody assays in early rheumatoid arthritis for predicting five year radiographic damage. Ann Rheum Dis 2003;62:120-6.

21 Vencovsky J, Machacek S, Sedova L, Kafkova J, Gatterova J, Pesakova V, et al. Autoantibodies can be prognostic markers of an erosive disease in early rheumatoid arthritis. Ann Rheum Dis 2003;62:427-30.

22 van Zeben D, Breedveld FC. Prognostic factors in rheumatoid arthritis. J Rheumatol Suppl 1996;44:31-3.

23 Young A, van der Heijde DM. Can we predict aggressive disease? Baillieres Clin Rheumatol, 1997;11:27-48.

24 Mottonen T, Paimela L, Leirisalo-Repo M, Kautiainen H, llonen J, Hannonen P. Only high disease activity and positive rheumatoid factor indicate poor prognosis in patients with early rheumatoid arthritis treated with "sawtooth" strategy. Ann Rheum Dis 1998;57:533-9.

25 Combe B, Dougados M, Goupille P, Cantagrel A, Eliaou JF, Sibilia J, et al. Prognostic factors for radiographic damage in early rheumatoid arthritis: a multiparameter prospective study. Arthritis Rheum $2001 ; 44: 1736-43$.

26 Bukhari M, Lunt M, Harrison BJ, Scott DG, Symmons DP, Silman AJ. Rheumatoid factor is the major predictor of increasing severity of radiographic erosions in rheumatoid arthritis: results from the Norfolk Arthritis Register Study, a large inception cohort. Arthritis Rheum 2002;46:906-12.

27 Teitsson I. IgA rheumatoid factor as predictor of disease activity. Scand J Rheumatol Suppl 1988;75:233-7.

28 Houssien DA, Jonsson T, Davies E, Scott DL. Clinical significance of IgA rheumatoid factor subclasses in rheumatoid arthritis. J Rheumatol 1997;24:2119-22.
29 Scott DL. Prognostic factors in early rheumatoid arthritis. Rheumatology (Oxford) 2000;39(suppl 1):24-9.

30 Visser H, Gelinck LB, Kampfraath AH, Breedveld FC, Hazes JM. Diagnostic and prognostic characteristics of the enzyme linked immunosorbent rheumatoid factor assays in rheumatoid arthritis. Ann Rheum Dis 1996;55:157-61.

31 Eberhardt KB, Svensson B, Truedsson L, Wollheim FA. The occurrence of rheumatoid factor isotypes in early definite rheumatoid arthritis - no relationship with erosions or disease activity. J Rheumatol 1988;15:1070-4.

32 Svenson M, Poulsen LK, Fomsgaard A, Bendtzen K. IgG autoantibodies against interleukin 1 alpha in sera of normal individuals. Scand J Immunol 1989;29:489-92.

33 Svenson M, Hansen MB, Kayser L, Rasmussen AK, Reimert CM, Bendtzen K. Effects of human anti-IL-1 alpha autoantibodies on receptor binding and biological activities of IL-1. Cytokine 1992;4:125-33.

34 Hansen MB, Andersen V, Rohde K, Florescu A, Ross C, Svenson M, et al. Cytokine autoantibodies in rheumatoid arthritis. Scand'J Rheumatol 1995;24:197-203.

35 Jouvenne P, Fossiez F, Garrone P, Diossou O, Banchereau J, Miossec P. Increased incidence of neutralizing autoantibodies against interleukin- 1 alpha (IL-1 alpha) in nondestructive chronic polyarthritis. J Clin Immunol 1996;16:283-90.

36 Jouvenne P, Fossiez F, Banchereau J, Miossec P. High levels of neutralizing autoantibodies against IL-1 alpha are associated with a better prognosis in chronic polyarthritis: a follow-up study. Scand J Immunol 1997;46:413-18.

37 Graudal NA, Svenson M, Tarp U, Garred P, Jurik AG, Bendtzen K. Autoantibodies against interleukin lalpha in rheumatoid arthritis: association with long term radiographic outcome. Ann Rheum Dis 2002;61:598-602.

38 Hansen MB, Svenson M, Abell K, Varming K, Nielsen HP, Bertelsen A, et al. Sex- and age-dependency of IgG auto-antibodies against IL-1 alpha in healthy humans. Eur J Clin Invest 1994;24(3):212-218.

39 Eberhardt K, Fex E, Johnson U, Wollheim FA. Associations of HLA-DRB and $D Q B$ genes with two and five year outcome in rheumatoid arthritis. Ann Rheum Dis 1996;55:34-9

40 Harrison B, Symmons D. Early inflammatory polyarthritis: results from the Norfolk Arthritis Register with a review of the literature. II. Outcome at three years. Rheumatology (Oxford) 2000;39:939-49.

41 Plant MJ, Jones PW, Saklatvala J, Ollier WE, Dawes PT. Patterns of radiological progression in early rheumatoid arthritis: results of an 8 year prospective study. J Rheumatol 1998;25:417-26.

42 Lindqvist E, Saxne T, Geborek P, Eberhardt K. Ten year outcome in a cohort of patients with early rheumatoid arthritis: health status, disease process, and damage. Ann Rheum Dis 2002;61:1055-9.

43 Lindqvist E, Jonsson K, Saxne T, Eberhardt K. Course of radiographic damage over 10 years in a cohort with early rheumatoid arthritis. Ann Rheum Dis 2003;62:611-16.

44 Larsen A, Dale K, Eek M. Radiographic evaluation of rheumatoid arthritis and related conditions by standard reference films. Acta Radiol Diagn (Stockh) 1977; 18:481-91.

45 Laurell CB. Electroimmuno assay. Scand J Clin Lab Invest Suppl 1972;124:21-37.

46 Lindqvist E, Eberhardt K. Mortality in rheumatoid arthritis patients with disease onset in the 1980s. Ann Rheum Dis 1999;58:11-14.

47 Eberhardt KB, Truedsson L, Pettersson H, Svensson B, Stigsson L, Eberhardt JL, et al. Disease activity and joint damage progression in early rheumatoid arthritis: relation to $\lg G, \lg A$, and $\lg M$ rheumatoid factor. Ann Rheum Dis 1990;49:906-9.

48 Schellekens GA, Visser $\mathrm{H}$, de Jong BA, van den Hoogen FH, Hazes JM, Breedveld FC, et al. The diagnostic properties of rheumatoid arthritis antibodies recognizing a cyclic citrullinated peptide. Arthritis Rheum 2000;43: 155-63.

49 Fex E, Eberhardt K, Saxne T. Tissue-derived macromolecules and markers of inflammation in serum in early rheumatoid arthritis: relationship to development of joint destruction in hands and feet. $\mathrm{Br} J$ Rheumatol 1997;36:1161-5.

50 Forslind K, Svensson B, Svenson M, Bendtzen K. Anti-IL-lalpha autoantibodies in early rheumatoid arthritis. Scand J Rheumatol 2001:30:167-8

51 Pincus T, Ferraccioli G, Sokka T, Larsen A, Rau R, Kushner I, et al. Evidence from clinical trials and long-term observational studies that diseasemodifying anti-rheumatic drugs slow radiographic progression in rheumatoid arthritis: updating a 1983 review. Rheumatology (Oxford) 2002;41:1346-56

52 Lard LR, Boers M, Verhoeven A, Vos K, Visser H, Hazes JM, et al. Early and aggressive treatment of rheumatoid arthritis patients affects the association of HLA class II antigens with progression of joint damage. Arthritis Rheum 2002;46:899-905. 